\title{
Geomicrobiology of Acid Mine Drainage in the weathering zone of pyrite-bearing schists in the Rudawy Janowickie Mountains (Poland)
}

\author{
Andrzej BORKOWSKI ${ }^{1, *}$, Jan PARAFINIUK ${ }^{2}$, Dorota WOLICKA ${ }^{2, * *}$ \\ and Paweł KOWALCZYK ${ }^{3}$
}

1 Department of Environmental Protection and Natural Resources, Faculty of Geology, University of Warsaw, Żwirki i Wigury 93, 02-089 Warszawa, Poland

2 Institute of Mineralogy, Geochemistry and Petrology, Faculty of Geology, University of Warsaw, Żwirki i Wigury 93, 02-089 Warszawa, Poland

3 Autonomous Department of Microbial Biology, Warsaw University of Life Sciences (SGGW), Nowoursynowska 159, 02-776 Warszawa, Poland

Borkowski A., Parafiniuk J., Wolicka, D. and Kowalczyk P. (2013) Geomicrobiology of Acid Mine Drainage in the weathering zone of pyrite-bearing schists in the Rudawy Janowickie Mountains (Poland). Geological Quarterly, 57 (4): 601-612, doi: $10.7306 / g q .1115$

We report geomicrobiological analysis of acid water reservoirs and Acid Mine Drainage (AMD) developed in the weathering zone of pyrite-bearing schists near the closed-down pyrite mine in Wieściszowice (southwestern Poland). The analysis focused on two reservoirs characterized by different physical and chemical properties ( $\mathrm{pH}$, redox potential, content of sulphates and heavy metals), emphasizing geomicrobiological relationships taking place in this AMD setting and describing the microbiological processes that significantly influence biogeochemical cycles of sulphur and iron in the water reservoirs analysed. The reservoir water also harbours numerous large, organized microbial structures in the form of streamers, studied in detail here using optical and electron microscopy and by microbiological cultivation and molecular methods. The Wieściszowice mine slime streamers are characterized by the co-occurrence of typical chemolithoautotrophic microorganisms oxidizing sulphur and iron together with sulphate-reducing bacteria. These structures probably depend on the occurrence of iron(II) in the surrounding environment.

Key words: Acid Mine Drainage, microbial communities, pyrite, weathering zone.

\section{INTRODUCTION}

Weathering zones of sulphide ores containing pyrite are places where chemical processes linked with the oxidation of sulphides of heavy metals are often accelerated by biotic processes, in which microorganisms play the main role. In this context, many geochemical and geomicrobiological studies are focused on Acid Mine Drainage and sulphur cycle microorganisms, such as chemolithoautotrophic sulphur bacteria and sulphate-reducing bacteria (Postgate, 1984; Gibson, 1990; Fauque et al., 1991; Hao et al., 1996; Nordstrom et al., 1999; Ehrlich, 2001; Hallberg, 2010). Many microorganisms oxidizing sulphide and sulphur also oxidize some metals, especially iron, thus favouring rapid development of the weathering zone, a

\footnotetext{
* Corresponding author, e-mail: a.borkowski@uw.edu.pl

** Deceased
}

Received: August 13, 2012; accepted: June 27, 2013; first published online: August 23, 2013 phenomenon that is difficult to attribute merely to chemical processes. One result of the microbial activity is the development of strongly acid conditions in the weathering zone of sulphidic ore deposits, resulting in the formation of acid mine drainage (Fortin et al., 1996; Johnson, 1998; Ehrlich, 2001; Baker and Banfield, 2003).

The weathering zone of the pyrite-bearing schists studied is located within the closed-down pyrite mine in Wieściszowice in Rudawy Janowickie, Western Sudetes (Fig. 1). Laminated chlorite-sericite schists mineralized with pyrite, forming a belt that is approximately $200 \mathrm{~m}$ wide and $4 \mathrm{~km}$ long, were subject to exploitation till 1925. The schists contain quartz, muscovite, chlorite, plagioclases, epidote and calcite. Pyrite mineralization impregnates the rock; its average content reaches approximately $10 \%$. The weathering zone developed in the mine workings yields a diverse paragenesis of secondary sulphate minerals (Table 1), such as gypsum, copiapite, pickeringite, fibroferrite, slavikite, melanterite, epsomite and schwertmannite (Balcerzak et al., 1992; Parafiniuk, 1996; Parafiniuk and Siuda, 2006).

Weathering processes of the pyrite schists exposed in the mine workings has resulted in a local hydrochemical anomaly characterized by high concentrations of sulphates and metal 


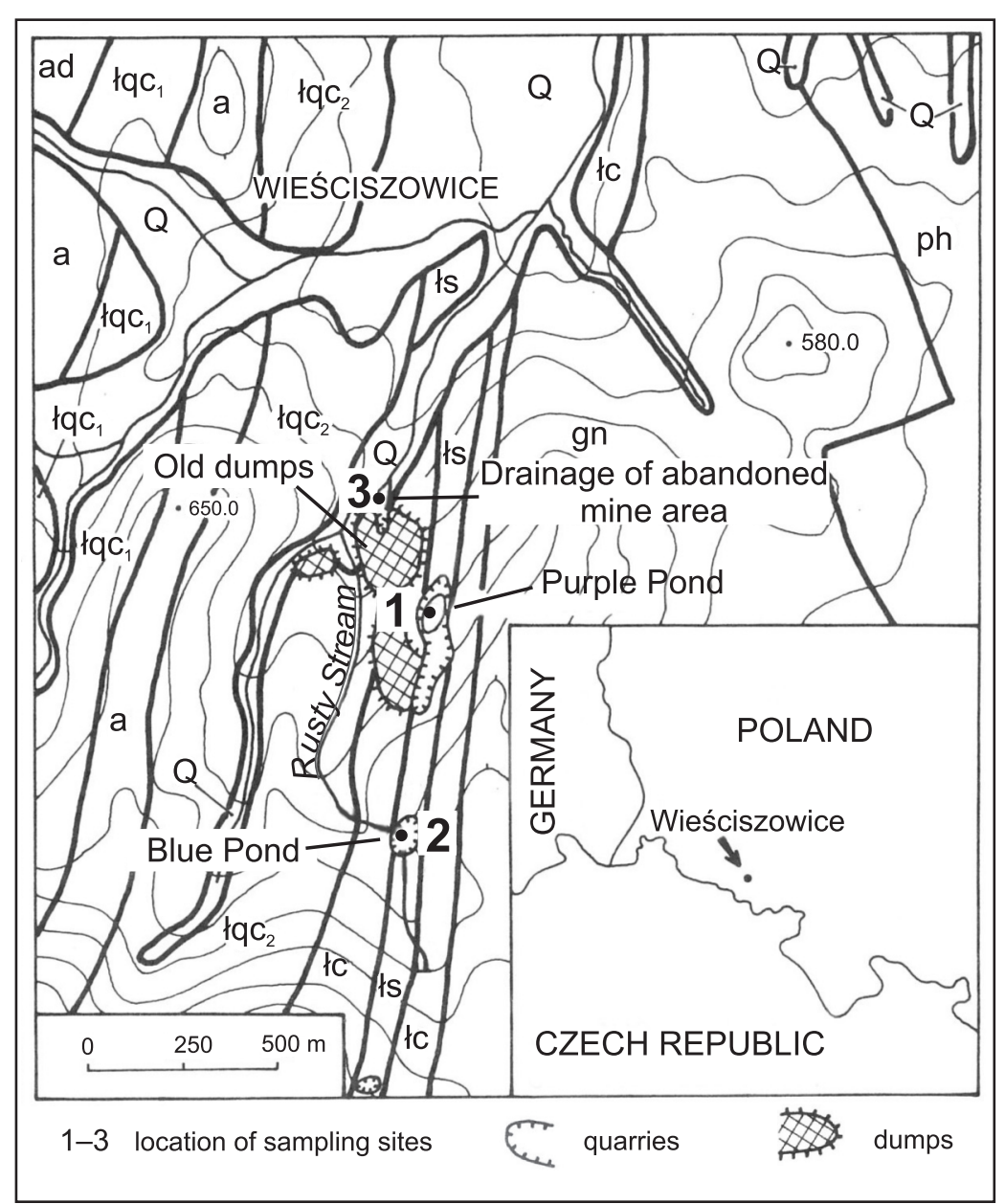

Fig. 1. Geological sketch of the environs of Wieściszowice (after Parafiniuk, 1996, modified)

a - amphibolites, ad - diopside amphibolites, gn - gneisses, łc - chlorite schists, łs - pyrite-bearing sericite-chlorite schists, $\mathfrak{ł q c}_{1}$ - massive quartz-chlorite schists, $\mathfrak{ł q c}_{2}$ - fibrous quartz-chlorite schists, ph - phyllites, Q - Quaternary deposits
The Blue Pond (150 $\mathrm{m}$ long, $35 \mathrm{~m}$ wide and about $10 \mathrm{~m}$ deep) fills a small, upper working of the mine situated at $650 \mathrm{~m}$ a.s.l. It is the deeper of the two and its water has a light bluish colour. The Purple Pond (max. $430 \mathrm{~m}$ long, $150 \mathrm{~m}$ wide and $2.5 \mathrm{~m}$ deep) is located deeper in the mine, in the largest mine working at a level of approximately $555 \mathrm{~m}$ a.s.l. and has dark brown colour and high mineralization. The Blue Pond is an overflow reservoir, whereas the Purple Pond does not have surface runoff and is drained through a series of fractures and underground mine workings by a small stream located below dumps of reworked pyrite-bearing schists (Fig. 2). The water level in both lakes is variable and depends on the meteorological conditions.

The geochemical characteristics of the reservoirs are apparent, but prior to this study were not subject to limnological and geomicrobiological studies. Large microbial aggregates growing in the small AMD-type stream draining water from the mine and the Purple Pond, likewise have not previously been studied microbiologically. These take the form of slime streamers, often larger than $20 \mathrm{~cm}$ : biofilms consisting of extensive deposits of extracellular substances in which microorganisms are embedded. Poorly crystalline iron oxyhydroxides are precipitated on the surface of the slime streamers. The presence of these structures is restricted to the upper part of the runoff. Such structures have not been noted in reservoirs filling the bottom of the workings.

Our investigations focused on the geomicrobiological characteristics of the water reservoirs and the AMD in Wieściszowice, and determining the influence of microbial communities on the biogeochemical cycles of sulphur and iron in the weathering zone of the pyrite-bearing schists.

\section{MATERIAL AND METHODS}

Water samples for chemical analysis were collected five times from each reservoir at a distance of approximately $1 \mathrm{~m}$ from the reservoir margin. In the field, the samples were filtered through a cellulose filter (millipore) at $0.45 \mu \mathrm{m}$ mesh size and transported airtight to the laboratory in order to determine the ions, especially those of $\mathrm{Fe}, \mathrm{Al}$, and $\mathrm{Mg}$ in ground and surface water. Water draining from the soluble weathering products fills the lowermost parts of the mine workings, forming small reservoirs, characterized in part by low $\mathrm{pH}$ and high mineralization typical of AMD. The two largest, the Purple Pond and Blue Pond, differ in colour and chemical composition of the water.

Sulphate minerals occurring in the weathering zone of pyrite-bearing schists at Wieściszowice

\begin{tabular}{|l|c|c|c|c|}
\hline \multicolumn{1}{|c|}{ Mineral } & Chemical formula & Solubility in water & Colour & Occurrence \\
\hline Fibroferrite & $\mathrm{Fe}(\mathrm{OH})\left(\mathrm{SO}_{4}\right) \cdot 5 \mathrm{H}_{2} \mathrm{O}$ & good & greyish & common \\
\hline Magnesocopiapite & $\mathrm{MgFeFe}_{4}^{3+}(\mathrm{OH})_{2}\left(\mathrm{SO}_{4}\right)_{6} \cdot 20 \mathrm{H}_{2} \mathrm{O}$ & very good & yellow & common \\
\hline Slavikite & $\mathrm{NaMg}_{2} \mathrm{Fe}_{5}^{3+}(\mathrm{OH})_{6}\left(\mathrm{SO}_{4}\right)_{7} \cdot 33 \mathrm{H}_{2} \mathrm{O}$ & good & green & rather common \\
\hline Pickeringite & $\mathrm{MgAl}_{2}\left(\mathrm{SO}_{4}\right)_{4} \cdot 22 \mathrm{H}_{2} \mathrm{O}$ & very good & white & rather common \\
\hline Melanterite & $\mathrm{FeSO}_{4} \cdot 7 \mathrm{H}_{2} \mathrm{O}$ & very good & whitish & rare \\
\hline Gypsum & $\mathrm{CaSO}_{4} \cdot 2 \mathrm{H}_{2} \mathrm{O}$ & poor & white & common \\
\hline Alunogen & $\mathrm{Al}_{2}\left(\mathrm{SO}_{4}\right)_{3} \cdot 18 \mathrm{H}_{2} \mathrm{O}$ & very good & white & rare \\
\hline Epsomite & $\mathrm{MgSO}_{4} \cdot 7 \mathrm{H}_{2} \mathrm{O}$ & very good & white & rare \\
\hline Schwertmannite & $\mathrm{Fe}_{8} \mathrm{O}_{8}(\mathrm{OH})_{8-2 x}\left(\mathrm{SO}_{4}\right)_{\mathrm{x}} \cdot \mathrm{nH}_{2} \mathrm{O}$ & very poor & brown & rather common \\
\hline
\end{tabular}



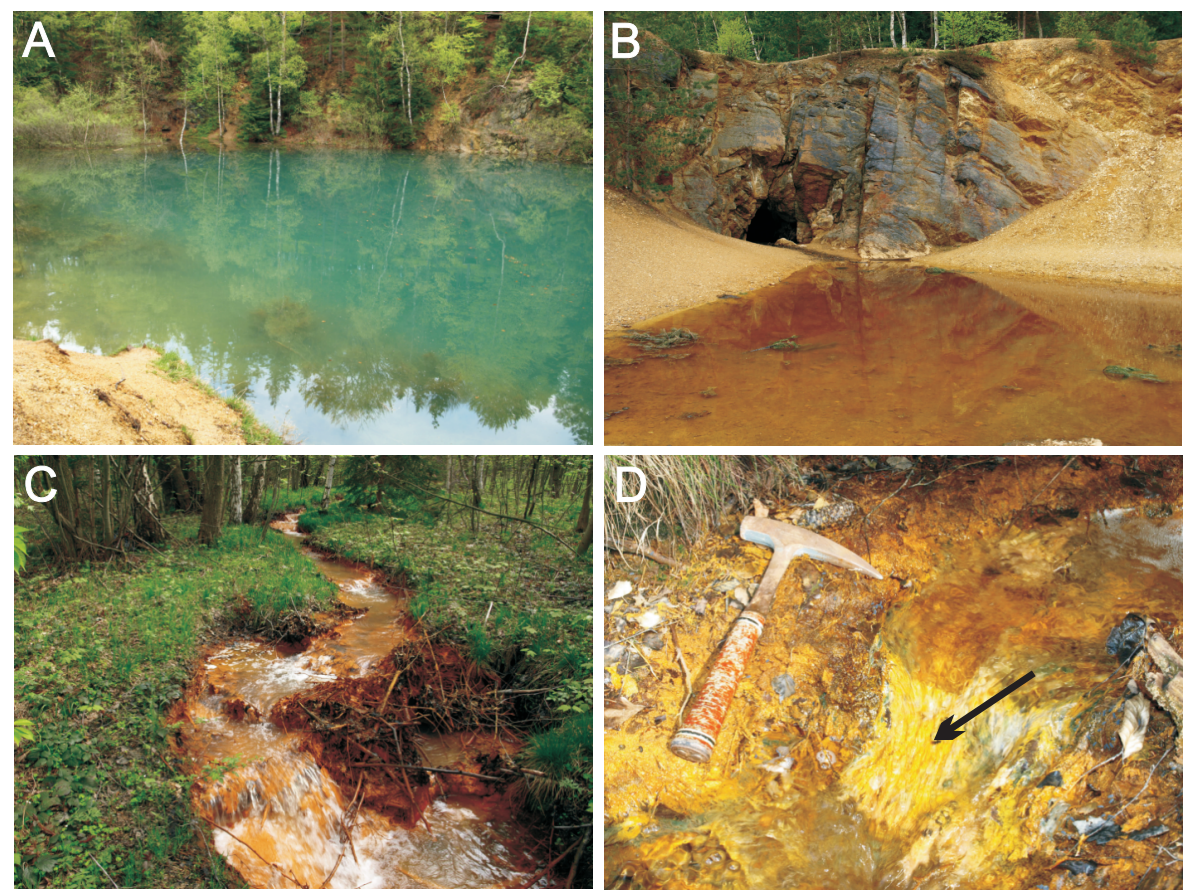

Fig. 2. Study area

A - Blue Pond; B - Purple Pond (height and width of outcrop - $7 \mathrm{~m}$ and $20 \mathrm{~m}$ respectively); C - stream from waste dump of reworked schists; D - slime streamers in the upper reach of the stream flowing from the waste dump (hammer is $35 \mathrm{~cm}$ long)

chemical composition. $\mathrm{Fe}^{2+}$ ions were detected in filtered field samples, acidified with $1 \mathrm{M} \mathrm{HCl}$. For microbiological analysis, five samples each were collected from the water and the bottom deposit from both water reservoirs and introduced into sterile $100 \mathrm{ml}$ containers. The samples of water were collected directly from the reservoir surface. The thickness of the samples of sediment was about $15 \mathrm{~cm}$. In addition, samples from microbial mats and from microbial communities occurring abundantly in AMD in streams draining the main mine working were collected.

The $\mathrm{pH}$ of the water was measured in the field with a combination electrode, and the redox potential of the water was measured using a carbon electrode.

\section{MICROBIOLOGICAL DETERMINATIONS}

The abundance of bacteria capable of thiosulphate oxidation was determined by plating samples on thiosulphate agar composed of: $\left(\mathrm{NH}_{4}\right)_{2} \mathrm{SO}_{4}-0.12 \mathrm{~g}, \mathrm{~K}_{2} \mathrm{HPO}_{4}-4.00 \mathrm{~g}, \mathrm{KH}_{2} \mathrm{PO}_{4}-$ $4.00 \mathrm{~g}, \mathrm{MgSO}_{4} \cdot 7 \mathrm{H}_{2} \mathrm{O}-0.10 \mathrm{~g}, \mathrm{CaCl}_{2}-0.10 \mathrm{~g}, \mathrm{FeCl}_{3} \cdot 6 \mathrm{H}_{2} \mathrm{O}-$ $0.03 \mathrm{~g}, \mathrm{MnSO}_{4} \cdot \mathrm{H}_{2} \mathrm{O}-0.02 \mathrm{~g}, \mathrm{Na}_{2} \mathrm{~S}_{2} \mathrm{O}_{3} \cdot 5 \mathrm{H}_{2} \mathrm{O}-10.00 \mathrm{~g}$, purified agar (Merck) $20 \mathrm{~g}$, and distilled water $1000 \mathrm{ml}(\mathrm{pH} 6.7$ ). The abundance of hyphal fungi capable of thiosulphate oxidation was determined on the same medium, but to which penicillin and streptomycin had been added. All determinations were made in triplicate by plating samples serially diluted in sterile $0.9 \% \mathrm{NaCl}$ solution.

Thiosulphate-oxidizing ability was studied in triplicate in enrichment cultures in the following medium: $\left(\mathrm{NH}_{4}\right) 2 \mathrm{SO}_{4}-0.12 \mathrm{~g}$, $\mathrm{K}_{2} \mathrm{HPO}_{4}-4.00 \mathrm{~g}, \mathrm{KH}_{2} \mathrm{PO}_{4}-4.00 \mathrm{~g}, \mathrm{MgSO}_{4} \cdot 7 \mathrm{H}_{2} \mathrm{O}-0.10 \mathrm{~g}$, $\mathrm{CaCl}_{2}-0.10 \mathrm{~g}, \mathrm{FeCl}_{3} \cdot 6 \mathrm{H}_{2} \mathrm{O}-0.03 \mathrm{~g}, \mathrm{MnSO}_{4} \cdot \mathrm{H}_{2} \mathrm{O}-0.02 \mathrm{~g}$, $\mathrm{Na}_{2} \mathrm{~S}_{2} \mathrm{O}_{3} \cdot 5 \mathrm{H}_{2} \mathrm{O}-10.00 \mathrm{~g}$, and distilled water $1000 \mathrm{ml}(\mathrm{pH} 6.7)$. Elemental sulphur-oxidizing ability was studied in triplicate enrichment cultures in the following medium: $\mathrm{NH}_{4} \mathrm{Cl}-0.12 \mathrm{~g}$, $\mathrm{KH}_{2} \mathrm{PO}_{4}-3.00 \mathrm{~g}, \mathrm{MgCl}_{2} \cdot 6 \mathrm{H}_{2} \mathrm{O}-0.10 \mathrm{~g}, \mathrm{CaCl}_{2} \cdot 2 \mathrm{H}_{2} \mathrm{O}-0.14 \mathrm{~g}$, powdered sulphur $10 \mathrm{~g}$, and distilled water $1000 \mathrm{ml}(\mathrm{pH} 4.2)$. Enrichment cultures from reservoir water or AMD were initiated with $5 \mathrm{ml}$ of respective inoculum. Enrichment cultures from bottom reservoir deposits or slime streamers were initiated with $1 \mathrm{~g}$ of respective inoculum. Each sample of the material studied was introduced to $50 \mathrm{ml}$ of medium and incubated at $25^{\circ} \mathrm{C}$ in a mechanical shaker. Incubation continued for two weeks, during which the concentration of sulphate ions was tested. Controls were set up like the corresponding enrichments, except that the respective inocula had been pretreated with $5 \%$ formaldehyde.

Similarly, $\mathrm{Fe}(\mathrm{II})$-oxidizing ability was determined in Silverman medium (Silverman and Lundgren, 1959) composed of: $\left(\mathrm{NH}_{4}\right)_{2} \mathrm{SO}_{4}-3.0 \mathrm{~g}, \mathrm{KCl}-0.1 \mathrm{~g}, \mathrm{~K}_{2} \mathrm{HPO}_{4}-0.5 \mathrm{~g}, \mathrm{MgSO}_{4}$. $7 \mathrm{H}_{2} \mathrm{O}-0.5 \mathrm{~g}, \mathrm{Ca}\left(\mathrm{NO}_{3}\right)_{2}-0.01 \mathrm{~g}, \mathrm{FeSO}_{4} \cdot 7 \mathrm{H}_{2} \mathrm{O}-44 \mathrm{~g}, \mathrm{H}_{2} \mathrm{SO}_{4}$ $(0.5 \mathrm{M}) 10 \mathrm{ml}$, and distilled water $1000 \mathrm{ml}$. The medium was sterilized by filtration. During incubation, measurements of $\mathrm{Fe}^{2+}$ ion concentrations were made and compared to readings of corresponding controls.

The selective medium Easicult S (Orion Diagnostica, Finland, Cat. No. 67687) was applied to reservoir water samples, reservoir bottom samples, and AMD to confirm the presence of sulphate reducing bacteria (SRB). Samples (approximately $100 \mu l)$ were inoculated aseptically by means of a sterile pipette into separate test tubes containing the test medium, which were then stoppered securely and incubated at $25^{\circ} \mathrm{C}$ for 7 days. Sulphate-reduction was indicated by blackening of a portion of the test medium.

\section{MICROSCOPY}

Microscopy was carried out with a scanning electron microscope outfitted with EDX (JEOL JSM-6380LA) and with an epifluorescence microscope (NIKON Eclipse E600W). For electron microscopy, the preparations were coated with carbon, 
whereas for fluorescence microscopy the samples were stained with acridine orange. The structure of microbial communities (streamers) from the AMD was tested in cross-sections of the structures studied using purpose-modified histological techniques as follows. A sample of the streamer $(0.5 \times$ $0.5 \mathrm{~cm}$ ) was fixed in the $4 \%$ formaldehyde in phosphate buffer $(0.1 \mathrm{M}, \mathrm{pH} 7)$ for $12 \mathrm{~h}$ and was dehydrated in a graded ethanol series ( $1 \mathrm{~h}$ in 50, 70, 80, 90 and 100\% ethanol). Next, the sample was cleared by immersing for $2 \mathrm{~h}$ in xylene and was transferred to a mixture consisting of equal parts of paraffin wax and xylene. After $2 \mathrm{~h}$, the sample was transferred to pure paraffin wax and placed in an oven $\left(60^{\circ} \mathrm{C}\right)$ for $5 \mathrm{~h}$. The sample was embedded in paraffin and sectioned using a microtome, and the sections were transferred to xylene and hydrated gently in serially diluted ethanol (100-50\%). Sections were stained with an aqueous mixture of methylene blue and eosine $(0.5 \%)$ for 2 minutes. The stained sections were dehydrated and mounted in DPX synthetic balsam.

\section{CHEMICAL DETERMINATIONS}

Sulphates in the cultures were measured using the turbidimetric method after reaction with barium chloride according to the method described by Kolmert et al. (2000); metal concentrations and total iron in the water samples from the reservoirs were determined using the ICP-OES method on an Optima $5300 \mathrm{DV}$ spectrometer. $\mathrm{Fe}^{2+}$ concentration in water samples was determined in a Thermo Scientific spectrophotometer after reaction with phenanthroline (Harvey et al., 1955).

\section{MOLECULAR ANALYSIS OF MICROORGANISMS AND DNA SEQUENCING}

Bacterial genomic DNA was extracted using a Genomic Mini isolation kit (A\&A Biotechnology) according to the manufacturer's instructions. The purity and concentration of DNA preparation were determined spectrophotometrically at $260 \mathrm{~nm}$, and the DNA was used as a template for Polymerase Chain Reaction (PCR). Approximately $100 \mathrm{ng}$ of DNA was used as the template for PCR amplification of nearly full-length bacterial 16S rRNA gene fragments using the universal primers 27F (5'AGAGTTTGATCCTGGCTCAG3') and 1492R (5'GGTTACCTTGTTACGACTT3') to amplify a 1540-bp segment from the 16S rRNA gene. AmpliTaq polymerase (Invitrogen) or MARATHON polymerase (A\&A Biotechnology) was employed in PCR reaction. The reactions were performed using a PTC-200 thermal cycler (MJ Research, Inc., USA) under optimized conditions: $95^{\circ} \mathrm{C}$ for $5 \mathrm{~min} ; 20$ cycles of $95^{\circ} \mathrm{C}$ for $30 \mathrm{~s}$, $53^{\circ} \mathrm{C}$ for $30 \mathrm{~s}, 72^{\circ} \mathrm{C}$ for $90 \mathrm{~s}$; followed by 15 cycles of $95^{\circ} \mathrm{C}$ for $30 \mathrm{~s}, 46^{\circ} \mathrm{C}$ for $30 \mathrm{~s}, 72^{\circ} \mathrm{C}$ for $1.5 \mathrm{~min}$; and a final extension at $72^{\circ} \mathrm{C}$ for $10 \mathrm{~min}$. Amplification products were purified using a NucleoSpin $®$ Extract I/ kit (Macherey-Nagel) and analysed by electrophoresis in $1 \%\left(\mathrm{wt}^{\mathrm{vol}} \mathrm{vo}^{-1}\right)$ agarose gel in a $1 \times \mathrm{TBE}$ running buffer containing ethidium bromide $\left(0.5 \mathrm{\mu g} \mathrm{m}^{-1}\right)$ at $4.8 \mathrm{~V} \mathrm{~cm}^{-1}$ for 1 h. A 100-bp DNA ladder (Invitrogen) was used as a size marker. Gels were photographed using a Syngene gel documentation system. The PCR products were directly sequenced on an ABI3730 DNA Analyzer (Applied Biosystems) using the primers 27F, 1492R, F357 (5'GCCTACGGAGGCAGCAG3'), 519R (5'ATTACCGCGGCTGCTGG3') and 926R (5'CCGTCAATTCCTTTGAGTTT3'), corresponding to the conserved regions of the $16 \mathrm{~S}$ rRNA gene sequence. DNA sequences were assembled using the Linux programs phred/phrap/consed and checked manually. The $16 \mathrm{~S}$ rDNA sequences obtained were then compared with those in the National Centre for Biotechnology Information (NCBI) database using the Blast 2.0 program. A multiple alignment with isolated sequences retrieved from the NCBI Reference mRNA and Microbes Assembled Genomes databases was generated using the program Muscle and edited manually using BioEdit (http://www.mbio.ncsu.edu/BioEdit/BioEdit.html).

\section{RESULTS}

\section{HYDROCHEMISTRY OF THE STUDIED WATER RESERVOIRS}

The chemical composition of water collected from surface layer in the reservoirs studied differed significantly. Samples from the Blue Pond showed slightly acid pH of approximately 5.5-6.0, and redox potential within 238-315 $\mathrm{mV}$ (Table 2). Sulphate concentration did not exceed $100 \mathrm{mg} \mathrm{I}^{-1}$, whereas the heavy metal concentration $(\mathrm{Co}, \mathrm{Ni}, \mathrm{Cu})$ was at the level of $0.01 \mathrm{mg} \mathrm{l}^{-1}$. Much higher values of the chemical elements analysed were noted in samples from the Purple Pond. High concentrations of $\mathrm{SO}_{4}^{2-}$ ions (about $2000 \mathrm{mg} \mathrm{I}^{-1}$ ) and of heavy metals were observed. Water from this reservoir was also characterized by much lower $\mathrm{pH}$ values, which were in the range of 2.5-3.0. The redox potential of water from this reservoir was within $430-550 \mathrm{mV}$. The content of iron in water samples from the two reservoirs was intriguing.

Table 2

The chemistry of water from the Blue Pond, Purple Pond and drainage of the abandoned mine area

\begin{tabular}{|c|c|c|c|}
\hline & Blue Pond & Purple Pond & Drainage \\
\hline $\mathrm{n}$ & 5 & 4 & 3 \\
\hline $\mathrm{pH}$ & $5.0-6.0$ & $2.5-3.0$ & $2.5-3.0$ \\
\hline Eh [mV] & $238-315$ & $456-590$ & $460-575$ \\
\hline \multicolumn{4}{|c|}{ macroelements $\left[\mathrm{mg} \mathrm{l}^{-1}\right]$} \\
\hline $\mathrm{Na}$ & $1.35-2.92$ & $4.69-5.27$ & $5.6-6.52$ \\
\hline $\mathrm{Mg}$ & $3.21-7.10$ & $88.1-140$ & $171-173$ \\
\hline $\mathrm{Al}$ & $0.79-2.12$ & $48.1-73.8$ & $65.7-94$ \\
\hline $\mathrm{Ca}$ & $13.5-16.7$ & $146-209$ & $173-326$ \\
\hline $\mathrm{Fe}^{2+}$ & n.d. & $35-61$ & 54 \\
\hline $\mathrm{Fe}_{\text {tot }}$ & $0.01-0.10$ & $113-131$ & $157-236$ \\
\hline $\mathrm{SiO}_{2}$ & $7.50-18.3$ & $46.4-50.9$ & $63.3-73.3$ \\
\hline $\mathrm{SO}_{4}^{2-}$ & $71-96$ & $2010-2440$ & $2389-2630$ \\
\hline \multicolumn{4}{|c|}{ microelements $\left[\mu \mathrm{g} \mathrm{I}^{-1}\right]$} \\
\hline $\mathrm{Li}$ & $7-9$ & $40-50$ & 60 \\
\hline $\mathrm{K}$ & $100-1380$ & $250-290$ & $600-670$ \\
\hline $\mathrm{Mn}$ & $70-160$ & $850-1870$ & $2700-3590$ \\
\hline Co & 10 & $160-240$ & $280-400$ \\
\hline $\mathrm{Ni}$ & 10 & $110-180$ & $190-270$ \\
\hline $\mathrm{Cu}$ & $<1-5$ & $1110-1280$ & $1470-2450$ \\
\hline $\mathrm{Zn}$ & $<1$ & $120-310$ & $390-550$ \\
\hline $\mathrm{Sr}$ & 20 & $100-170$ & $270-390$ \\
\hline $\mathrm{Pb}$ & $3-5$ & 5-8 & 8 \\
\hline $\mathrm{PO}_{4}^{3-}$ & $<3$ & $<3$ & $<3-200$ \\
\hline
\end{tabular}

$\mathrm{n}$ - count of samples; n.d. - not determined 
In the Blue Pond the concentration of total iron did not exceed $0.1 \mathrm{mg} \mathrm{I}^{-1}$, whereas in the Purple Pond it lay between 114-132 $\mathrm{mg} \mathrm{l}^{-1}$. Moreover, in samples from the Purple Pond the presence of ferrous ions at a level of $45 \mathrm{mg} \mathrm{l}^{-1}$ was noted, which was about $37 \%$ of the total iron in the solution (averagely $124 \mathrm{mg} \mathrm{I}^{-1}$ ). This is a significant result, particularly in the context of the presence of iron(II)-oxidizing bacteria at a very low $\mathrm{pH}$. Very similar concentrations of the chemical solutes studied were obtained from the AMD stream flowing out below the Purple Pond. In general, the water from the Purple Pond was homogeneous and the redox potential was similar throughout the entire column of water. However, the Blue Pond seems to be vertically zoned as regards the depth and concentration of $\mathrm{H}_{2} \mathrm{~S}$. The redox potential decreased with depth from a value of ca. $260 \mathrm{mV}$ to ca. $-50 \mathrm{mV}$ near the bottom. The content of $S^{2-}$ in a sample of water collected with sediment (at a distance of approximately $1 \mathrm{~m}$ from the reservoir margin) was about $1.5 \mathrm{mg} \mathrm{l}^{-1}$.

\section{ABUNDANCE AND ACTIVITY OF MICROORGANISMS IN ENRICHED CULTURES}

Analysis of the abundance of bacteria oxidizing thiosulphate determined on thiosulphate agar showed significant differences between the water reservoirs studied (Fig. 3). In samples from the Blue Pond the abundance in the bottom deposit was at the level of $10^{5} \mathrm{cfu} \mathrm{g}_{\mathrm{d} . \mathrm{m}^{-1}}{ }^{-1}$ (colony-forming units $/ \mathrm{g}$ dry mass), whereas in the deposit from the Purple Pond this abundance was smaller, on average $10^{2}-10^{3}$ cfu gd.m. ${ }^{-1}$. Similarly, water samples from the Blue Pond displayed much higher abundances of the bacteria than similar water samples from the Purple Pond. Analysis also revealed a considerable content of hyphal fungi growing on the thiosulphate agar. Detection of their abundance in agar, with addition of antibiotics inhibiting bacterial growth, indicated that in both reservoirs the fungi growing on thiosulphate agar were equally abundant $\left(103 \mathrm{gd}_{\mathrm{d} . \mathrm{m}^{-1}}\right)$ and their occurrence was essentially restricted to the bottom deposit.

The potential thiosulphate- and elemental sulphur-oxidizing ability as well as the Fe(II)-oxidizing ability of enrichment cultures prepared with water- and bottom deposit-samples was quantified (Figs. 4 and 5). The initial pH of the medium for observing thiosulphate-oxidizing activity was 6.7 and for observing elemental-sulphur oxidizing activity was 4.2 . The amount of sulphate production after 10 days of incubation of the various culture enrichments in the thiosulphate medium was a measure of the potential thiosulphate-oxidizing activity contributed by the

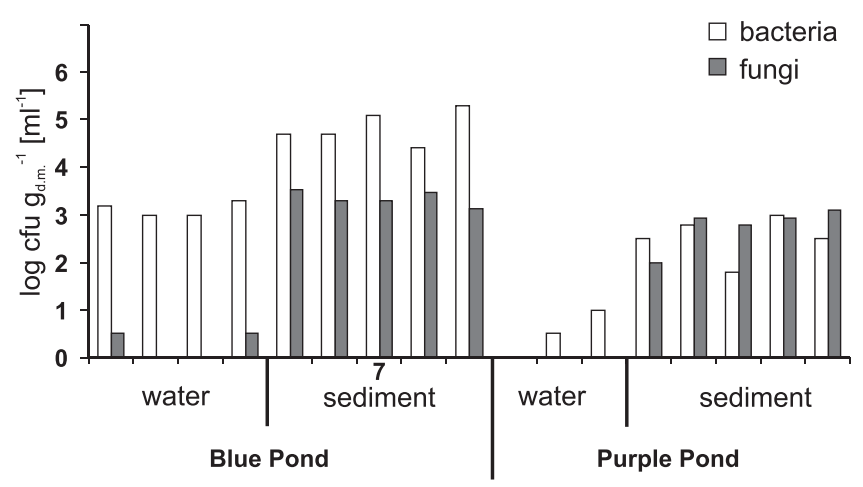

Fig. 3. An abundance of bacteria and hyphal fungi in samples of water and sediment from Blue and Purple ponds, determined on thiosulphate agar respective enrichment inocula. It correlated with the bacterial abundance in the respective inocula enumerated on thiosulphate agar. In enrichment cultures inoculated with samples of deposits from the Blue Pond an increase of $\mathrm{SO}_{4}^{2-}$ concentration by almost $4000 \mathrm{mg} \mathrm{I}^{-1}$ was observed after 10 days. In the case of cultures from the Purple Pond, such concentrations were noted only in one enriched culture with a sample of the bottom deposit. The opposite trend was observed in enrichment

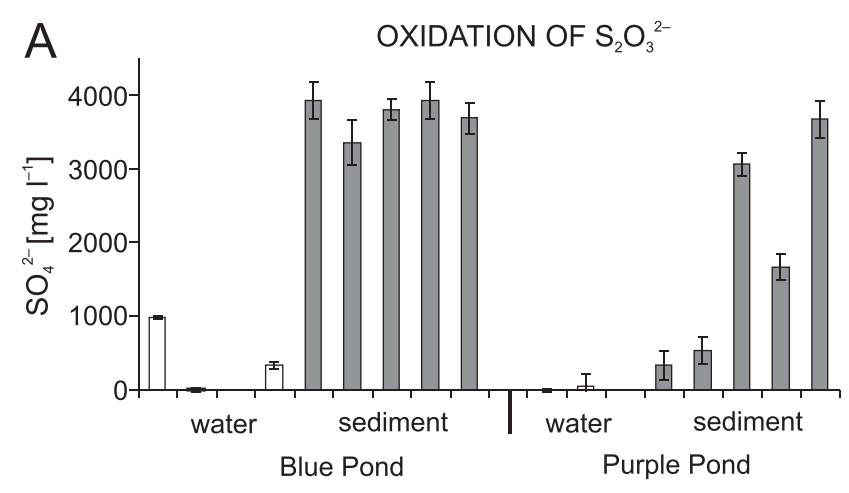

B

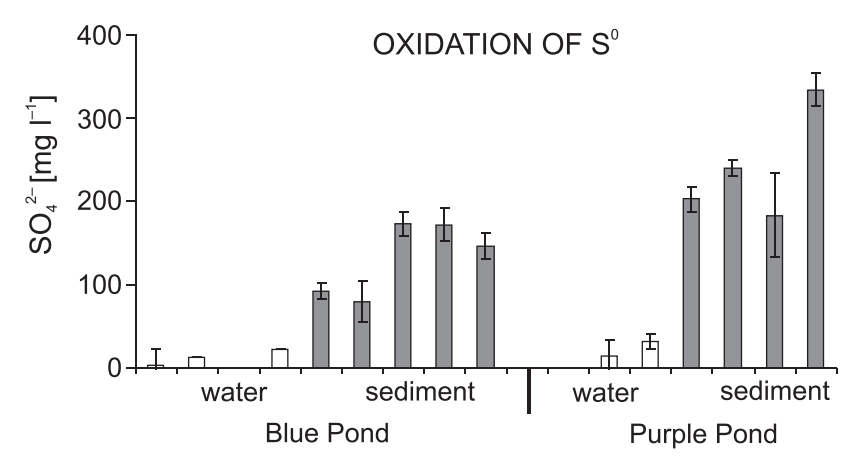

Fig. 4. Increase of $\mathrm{SO}_{4}^{2-}$ ion concentration in enriched cultures after 10 days of incubation on medium with thiosulphate (oxidation of $\mathrm{S}_{2} \mathrm{O}_{3}^{2-}$ ions) - $A$ and on medium with elemental sulphur (oxidation of $S^{0}$ ) - B

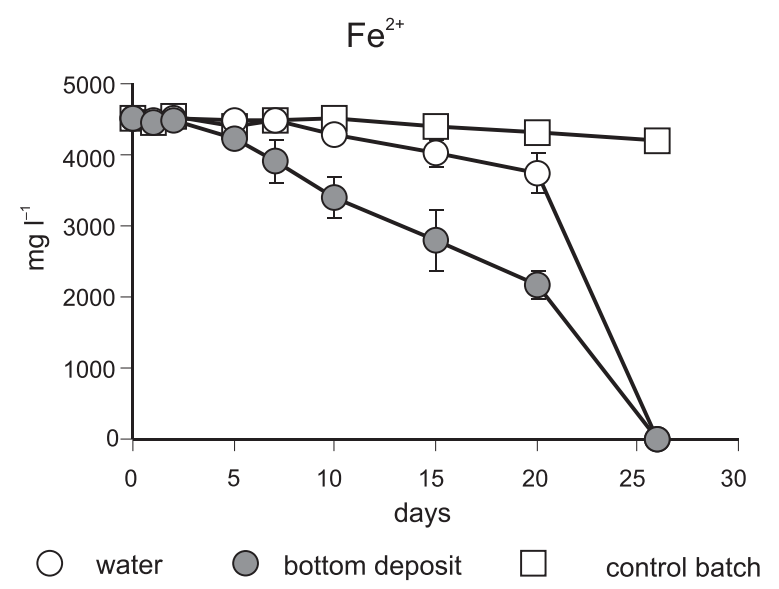

Fig. 5. Changes of $\mathrm{Fe}^{2+}$ concentration in cultures inoculated with material from the Purple Pond

Standard deviation is shown 
cultures prepared in an elemental-sulphur medium. Here, the $\mathrm{SO}_{4}^{2-}$ ion concentrations determined were higher in enrichment cultures inoculated with bottom deposit from the Purple Pond.

A decrease in iron(II) concentration was noted in enrichment cultures prepared in Silverman medium inoculated with water or bottom samples from the Purple Pond (Fig. 5). Iron oxidation resulted in the change of the solution colour to yellow-brown and precipitation of brown mineral phases. After 26 days, the decrease in iron concentration reached $100 \%$ compared to the control, whereas no iron(II) oxidation was observed in Silverman medium-enrichment cultures inoculated with water- or bottom-samples from the Blue Pond.

\section{ANALYSIS OF MICROBIAL COMMUNITY (SLIME STREAMERS) FROM THE AMD}

In the small AMD stream draining water from the main mine working, natural, grey-white and light brown, compact, mucilaginous streamers of microbial growth up to $20 \mathrm{~cm}$ long were present in dense formations on deposit fragments and at the margin of the upper reach of the stream (Fig. 2D). Microscopic analysis (Figs. 6 and 7) showed the presence of microorganisms in these structures with sizes typical of bacteria $(2-5 \mu \mathrm{m})$, variable morphologically, secreting large quantities of slime that formed the mucilaginous structure of the streamer. Other from bacterial cells, dense groups of green cells randomly distributed on the streamer surface were also observed. Analysis using an electron microscope with an energy-dispersive X-ray spectroscopy (EDX) detector showed the presence of oxygen and iron on the surface of the fragments studied, as well as areas highly enriched in sulphur. Cross-sections of the streamer examined showed a fragmented layered structure on which poorly crystalline mineral material was locally present. Fluorescence microscopy confirmed the presence of variable morphotypes of bacteria in the streamer, as well as clusters of microbial cells showing autofluorescence, probably belonging to cyanobacteria.

In order to determine the ability of the microbial streamer studied to oxidize elemental sulphur and iron, an experiment was conducted under laboratory conditions, in which fragments
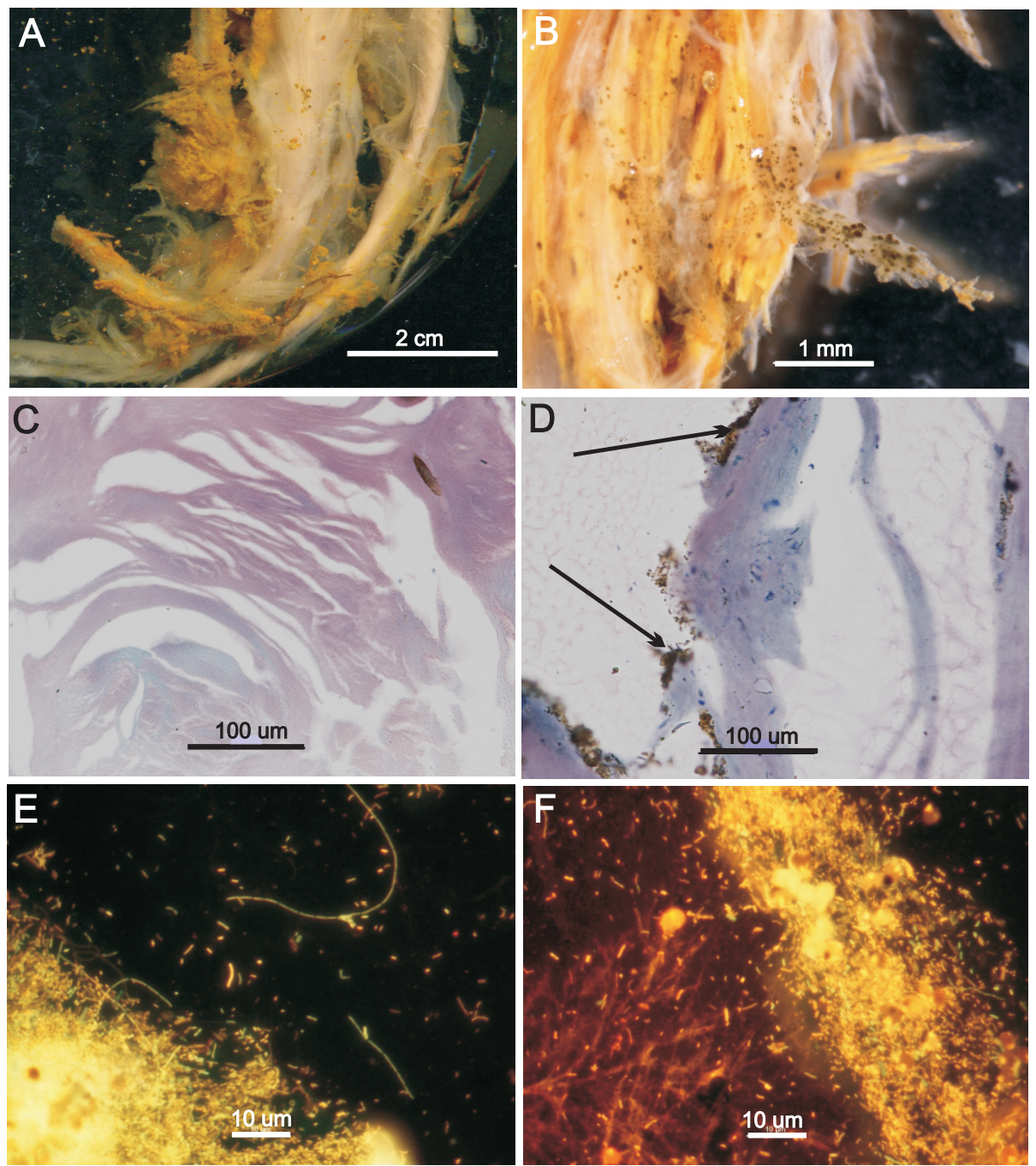

Fig. 6. Microbial community (slime streamers) from the stream flowing from the schist waste dump

A - general morphology of a streamer; B - streamer fragments viewed with a stereoscopic microscope; small clusters of photosynthesizing microorganisms are visible; C, D - cross-section of a streamer; poorly crystallized iron oxyhydroxides on surface of the layered structure are marked; E, F - streamer fragments viewed with fluorescence microscopy 

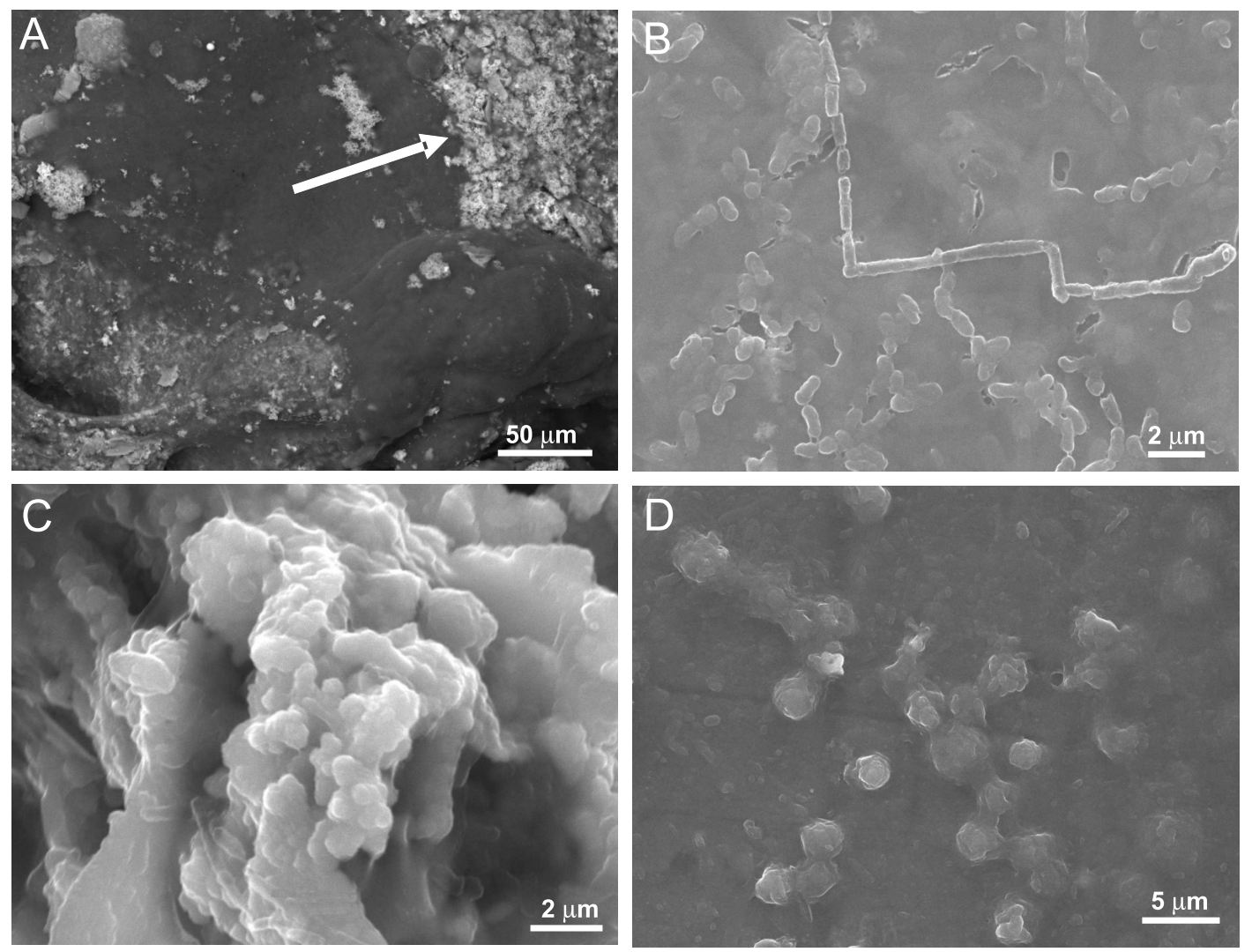

Fig. 7. Microbial community (slime streamers) from the stream flowing from the schist waste dump (SEM)

A - streamer surface in slight magnification, poorly crystallized iron oxyhydroxides covering the surface are marked; B, C - streamer surface; D - microorganism cells on the streamer surface visible as green concentrations in light microscopy

of slime streamers were inoculated into the microbiological media described above. Plots in Figure 8 show changes in sulphate and iron(II) concentration compared to the control batch. These experiments showed that the microbes in the streamer inoculum were able to oxidize elemental sulfur and iron under acid conditions. Easicult $\mathrm{S}$ tests indicated the presence of microorganisms capable of sulphate reduction.

Identification of microorganisms comprising the slime streamers studied and microbial communities within the bottom deposits in both water reservoirs required isolation of DNA and sequencing a fragment of gene 16S rRNA; the results were compared with genome fragments of known microorganism strains in existing databases (Tables 3 and 4). Analysis showed that the sequenced fragments of gene 16S rRNA indicate significant similarity to strains that were either autotrophs or heterotrophs. Material from slime streamers showed the presence of strains similar to bacteria typical of the AMD environment, such as Acidithiobacillus ferrooxidans, but also typically saprophytic bacteria such as Bacillus subtilis or $B$. amyloliquefaciens. It is interesting that the presence of SRB e.g., Desulfococcus oleovorans and Desulfotalea psychrophila was also detected. In turn, the SRB were present in significant numbers in the bottom deposits of both the Purple and the Blue ponds.

We also isolated and characterized 16S rRNA genes from streamer fragments that harbored photosynthetic microbes.
The analysis (Table 3) showed the presence of cyanobacteria e.g., representing the genera Arthrospira, Acaryochloris, Cyanobium, Cyanothece and Synechococcus.

\section{DISCUSSION}

The Purple Pond was characterized by significantly higher mineralization and higher concentration of heavy metals compared to the Blue Pond. This might seem mainly the effect of differences in hydrology, though it is also possible that the hydrogen sulphide in the Blue Pond can affect the concentration of metals, which can be precipitated as sulphides and retained in the sediments. The Blue Pond is recharged and drained by water from the nearby Rusty Stream. The Purple Pond does not have a surface runoff, but to a minor extent its drainage is possible through the basement and the underground mine workings. Water of the Purple Pond collects much more acid products of weathering of the pyrite-bearing schists than the Blue Pond, which fills with water in contact with poorly exposed schists in the smaller mine working. Both these factors cause significant differences in water chemistry (Balcerzak et al., 1992; Parafiniuk, 1996). During weathering, the pyrite-bearing schists exposed in the mine supplies considerable amounts of sulphates, iron, magnesium, aluminium, calcium and other prod- 


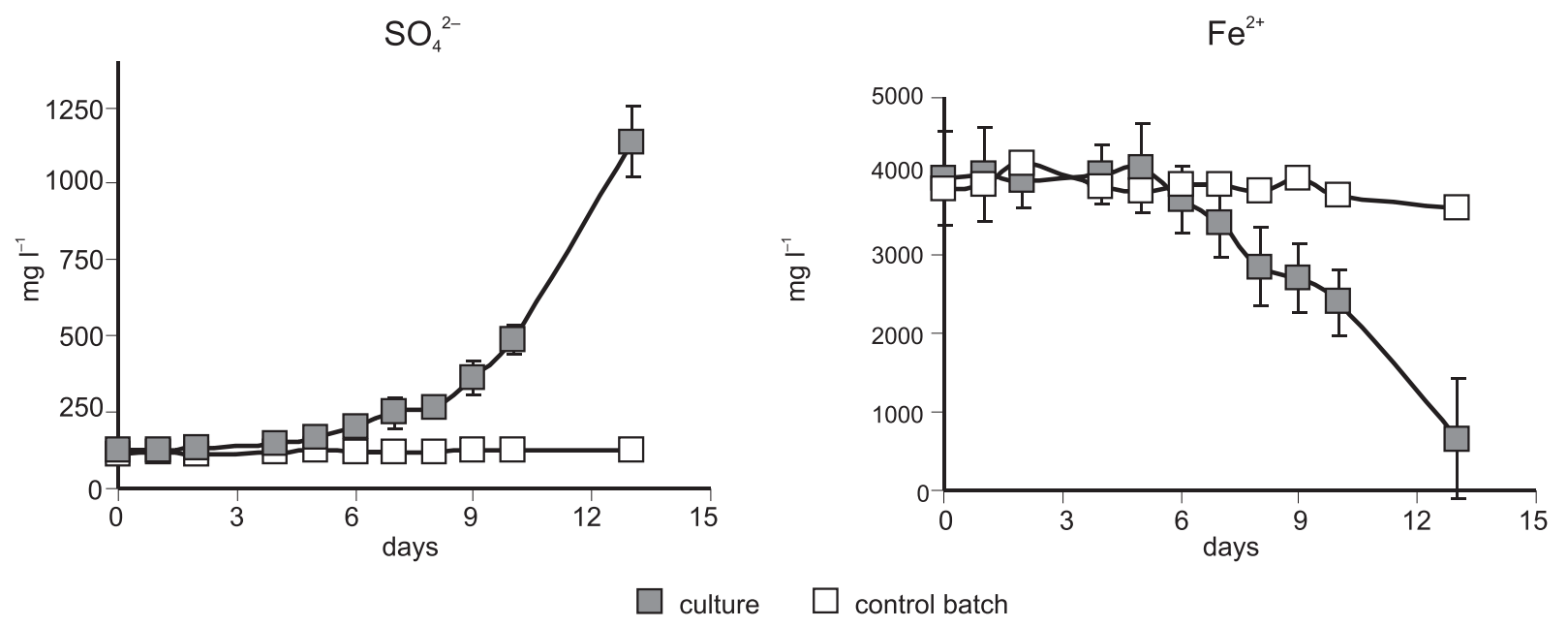

Fig. 8. Changes of $\mathrm{SO}_{4}^{2-}$ and $\mathrm{Fe}^{2+}$ concentrations in cultures with material from slime streamers from the acid runoff stream from the schist waste dump

Standard deviation is shown

Table 3

Genetic analysis (16S rRNA) of the bacterial community from slime streamers isolated from drainage of the mine nearby the Purple Pond

\begin{tabular}{|c|c|c|}
\hline Strain & $\begin{array}{c}\text { Similarity } \\
{[\%]}\end{array}$ & Site of isolation \\
\hline Acidaminococcus sp. D21 cont 1.71 & 90 & \multirow{14}{*}{$\begin{array}{l}\text { bacteria from slime } \\
\text { streamers } \\
\text { (drainage of mine) }\end{array}$} \\
\hline Acidithiobacillus ferrooxidans ATCC 23270 & 86 & \\
\hline Acidithiobacillus ferrooxidans ATCC 53993 & 85 & \\
\hline Acidothermus cellulolyticus 11B & 87 & \\
\hline Acinetobacter baumanii AB0057 & 82 & \\
\hline Aeromonas salmonicida & 72 & \\
\hline Bacillus amyloliquefaciens & 95 & \\
\hline Bacillus coagulans 36D1 ctg473 & 94 & \\
\hline Bacillus subtilis SMY & 96 & \\
\hline Desulfococcus oleovorans $\mathrm{Hxd} 3$ & 89 & \\
\hline Desulfotalea psychrophila LSv54 & 91 & \\
\hline Pseudomonas syringae $1448 \mathrm{~A}$ & 88 & \\
\hline Staphylococcus saprophyticus ATCC 15305 & 98 & \\
\hline Streptococcus thermophilus CNRZ1066 & 93 & \\
\hline Arthrospira platensis str. Paraca & 100 & \multirow{14}{*}{$\begin{array}{c}\text { cyanobacteria from slime } \\
\text { streamers } \\
\text { (drainage of mine) }\end{array}$} \\
\hline Arthrospira sp. PCC 8005 & 99 & \\
\hline Arthrospira maxima CS-328 & 99 & \\
\hline cyanobacterium UCYN-A & 98 & \\
\hline Acaryochloris marina MBIC11017 & 97 & \\
\hline Cyanobium sp. PCC 7001 & 96 & \\
\hline Cyanothece sp. CCY0110 & 96 & \\
\hline Cyanothece sp. PCC 8801 & 96 & \\
\hline Cyanothece sp. PCC 8802 & 96 & \\
\hline Thermosynechococcus elongatus BP-1 & 95 & \\
\hline Trichodesmium erythraeum IMS101 & 94 & \\
\hline Nostoc azollae 0708 & 93 & \\
\hline Anabaena variabilis ATCC 29413 & 92 & \\
\hline Synechococcus sp. CC9902 & 91 & \\
\hline
\end{tabular}

ucts of erosion that have a fundamental influence on the water chemistry in these reservoirs. Strong acidification by products of pyrite oxidation results in the formation of unstable mineral phase of chlorite and sericite schists, particularly chlorite, whose decomposition is the main source of magnesium, aluminium and calcite supplying calcium to the reservoirs studied. A characteristic feature is the very low concentration of alkali resulting from the resistance of sericite to decomposition in an acid environment (Parafiniuk, 1996).

Acid water reservoirs such as those occurring near Wieściszowice are also known from many weathering zones around other sulphide ore deposits. With regard to chemical composition, they are similar to other widely discussed occurrences of AMD (Murad et al., 1994; Webster et al., 1994; Leduc et al., 2002; Joeckel et al., 2005). Limnological, microbiological and hydrogeochemical studies of such reservoirs, formed in pyrite mines near Rio Tinto in the "Spanish Pyrite Belt", have been published by Sánchez-España et al. (2008), GonzálezToril et al. (2011) and Sánchez-Andrea et al. (2011). Water from these reservoirs is characterized by physical and chemical properties similar to those found in the workings of the Wieściszowice mine. Chemical characteristics mentioned by Sánchez-España et al. (2008) vary from neutral, with relatively low metal content, e.g., the Los Frailes reservoir $\left(\mathrm{pH}=7.2,0.07 \mathrm{mg} \mathrm{Fe} \mathrm{I}^{-1}\right)$ to extremely acid such as the Corta Atalaya with $\mathrm{pH}=1.2$, iron 
Table 4 ronment. Although molecular analysis (16S rRNA) did not indicate the presence of bacteria similar to Acidithiobacillus sp.

Genetic analysis (16S rRNA) of the sediment samples from the Blue and Purple ponds

\begin{tabular}{|c|c|c|}
\hline Strain & $\begin{array}{c}\text { Similarity } \\
{[\%]}\end{array}$ & Site of isolation \\
\hline Desulfatibacillum alkenivorans AK-01 & 90 & \multirow{8}{*}{$\begin{array}{l}\text { sediment from } \\
\text { the Blue Pond }\end{array}$} \\
\hline Desulfovibrio salexigens DSM 2638 ctg4 & 95 & \\
\hline Geobacillus kaustophilus HTA426 & 92 & \\
\hline Geobacillus thermodenitrificans NG80-2 & 85 & \\
\hline Marinobacter aquaeolei VT8 & 95 & \\
\hline Methanococcoides burtonii DSM 6242 & 90 & \\
\hline Shewanella baltica OS185 & 99 & \\
\hline Shewanella putrefaciens $200 \mathrm{ctg} 6$ & 95 & \\
\hline Anaeromyxobacter dehalogenans 2CP-C & 88 & \multirow{14}{*}{$\begin{array}{l}\text { sediment from } \\
\text { the Purple Ponc }\end{array}$} \\
\hline Coprothermobacter proteolyticus DSM 5265 & 68 & \\
\hline Desulfatibacillum alkenivorans AK-01 & 91 & \\
\hline Desulfococcus oleovorans $\mathrm{Hxd} 3$ & 93 & \\
\hline Desulfohalobium retbaense DSM 5692 & 86 & \\
\hline Desulfohalobium retbaense DSM 5692 & 85 & \\
\hline Desulfomicrobium baculatum DSM 4028 & 87 & \\
\hline Desulfotomaculum reducens $\mathrm{Ml}-1$ & 96 & \\
\hline Desulfuromonas acetoxidans DSM $684 \mathrm{ctg}$ & 97 & \\
\hline Dialister invisus DSM 15470 & 80 & \\
\hline Thermoanaerobacter pseudethanolicus ATCC 332 & 90 & \\
\hline Thermus thermophilus HB27 & 71 & \\
\hline Thioalkalivibrio sp. HL-EbGR7 & 95 & \\
\hline Thioalkalivibrio sp. K90mix ctg2 & 95 & \\
\hline
\end{tabular}

content $\left(36.7 \mathrm{~g} \mathrm{I}^{-1}\right)$ and copper content $\left(1.3 \mathrm{~g} \mathrm{I}^{-1}\right)$. Most of these basins are, however, typical acid reservoirs with $\mathrm{pH}$ within 2.2-3.6 (Sánchez-España et al., 2008), for which interesting microbiological investigations were also presented. These may allow for conclusions on the key role of bacteria oxidizing $\mathrm{Fe}^{2+}$ in the iron cycle in the environments described and the role of bacteria reducing iron, whose activity may be the source of $\mathrm{Fe}^{2+}$ ions.

Microbiological analysis of the Wieściszowice reservoirs indicates significant differences between these basins, reflected in the comparison of bacterial abundance determined on thiosulphate agar and in the results from culture enrichments. The most important cause of these differences is probably the chemical composition of water from the respective reservoirs. In the Blue Pond the $\mathrm{pH}$ is only slightly acid and there is high production of hydrogen sulphide that may be oxidized by sulphur bacteria, which do not necessarily belong to acidophilic species. Such bacteria, e.g. Thiobacillus, very often have the ability to oxidize both hydrogen sulphide and thiosulphate (Holt et al., 2000). Due to instability at pH below 4 (Pronk, 1990), thiosulphate is available to sulphur bacteria only at neutral or slightly acid $\mathrm{pH}$. Thiosulphate oxidation is a property not only of sulphur bacteria; it is, however, a feature often occurring in chemolithoautotrophic microorganisms capable of growth on thiosulphate as the sole energy source (Kappler et al., 2001). All samples of deposits from the Blue Pond in enriched cultures resulted in considerable increase of sulphate concentration from thiosulphate oxidation by contrast to cultures with elemental sulphur under acid conditions. The opposite relationship was noted in the case of the Purple Pond, from which samples in cultures enriched with sulphur yielded much higher concentrations of sulphates in comparison to samples from the Blue Pond. This may indicate the presence of microorganisms capable of elemental sulphur oxidation and preferring an acid envi- in the Purple Pond, their presence was noted in samples of streamers growing in the stream from the waste dump with a chemical composition similar to that from the Purple Pond. These streamers are an interesting example of a microbial assemblage composed of many different microorganisms. The bacterial communities in the streamers vary in composition with respect to organisms capable of oxidizing elemental sulphur and iron, and also with respect to SRB and cyanobacteria. A crucial role in the streamers is assumed to be played by microorganisms capable of iron oxidation because these streamers are present only in the uppermost stretch of the stream flowing from the waste dump, where a significantly high concentration of iron(II) is still noticeable. Further downstream, $\mathrm{Fe}^{2+}$ concentration decreases and considerable amounts of precipitating mineral phases with iron(III) appear. Similar structures in an AMD environment were studied by Bond et al. (2000), who noted the presence of microorganisms classified into Acidithiobacillus, Leptospirillum and Sulfobacillus. The occurrence of SRB in the streamers was an interesting observation. Their presence was supported both by molecular analysis and in cultivation tests. Such microorganisms were noted in both water reservoirs studied. Most known SRB are heterotrophic species, strictly anaerobic, preferring neutral or slightly alkaline environments, growing in the presence of sulphate ions (Gibson, 1990; Rampinelli et al., 2008). Such conditions occur in the Blue Pond, which is shown by the presence of hydrogen sulphide in this reservoir. The second reservoir, the Purple Pond, does not seem as favourable to these bacteria, although all genetic analyses of samples collected from this setting indicate the presence of SRB. It seems that some species belonging to this group of microorganisms are not sensitive to acid conditions (Praharaj and Fortin, 2004; Rampinelli et al., 2008). It seems that low $\mathrm{pH}$ value is not necessarily a limiting factor for SRB activity. It is possible that the quantity and quality of organic carbon can strongly affect the SRB metabolism (Koschorreck, 2008). Moreover, some analyses indicate the ability of SRB to grow under microaerophilic conditions, particularly in bacterial communities (Baumgartner et al., 2006).

It seems thus that the group may play a significant role in acid environments such as the AMD in Wieściszowice, particularly considering the fact that such waters are usually enriched in sulphates due to oxidation of sulphide minerals.

\section{SUMMARY AND CONCLUSIONS}

The occurrence of microbial communities capable of oxidizing inorganic compounds of sulphur and iron within acid water reservoirs is linked to the presence of mineral compounds acting as the source of energy in these waters. The presence of typical microorganisms capable of full oxidation of thiosulphate to sulphates is demonstrated, as well as the pres- 
ence of SRB, which is significant because of the acid reaction of these reservoirs and their high redox potential. In the Blue Pond, water $\mathrm{pH}$ was determined to be in the range of $5-6$, which favours the growth of SRB as well as sulphur microorganisms preferring a slightly acid environment, whereas the very low water $\mathrm{pH}$ and high redox potential in the Purple Pond is presumably not favourable for the development of SRB. However, this group of bacteria was found both in culture tests and by molecular analysis.

Differences in the water chemistry between the reservoirs studied are reflected in the potential activity of the isolated microbial communities capable of thiosulphate oxidation. Culture experiments showed that the microorganism assemblage isolated from the Purple Pond was characterized by lower potential ability characterized by differences in physiology. Culture tests and molecular studies showed the presence of microorganisms oxidizing iron within the slime streamers and it seems that the biotic process of iron(II) to iron(III) oxidation successfully competes with its abiotic oxidation in flowing water conditions, resulting in the development of numerous microbial structures, possibly physiologically also utilizing this process. The analyses allow tentative determination of microbiological processes linked to the sulphur and iron cycle. Figure 9 shows a scheme of processes that may have crucial meaning for the shaping of the biogeochemical cycle of sulphur and iron in two chemically different water reservoirs in the weathering zone of the pyritebearing schists at Wieściszowice. In the Blue Pond the dominating processes in the sulphur cycle are the microbiological re-

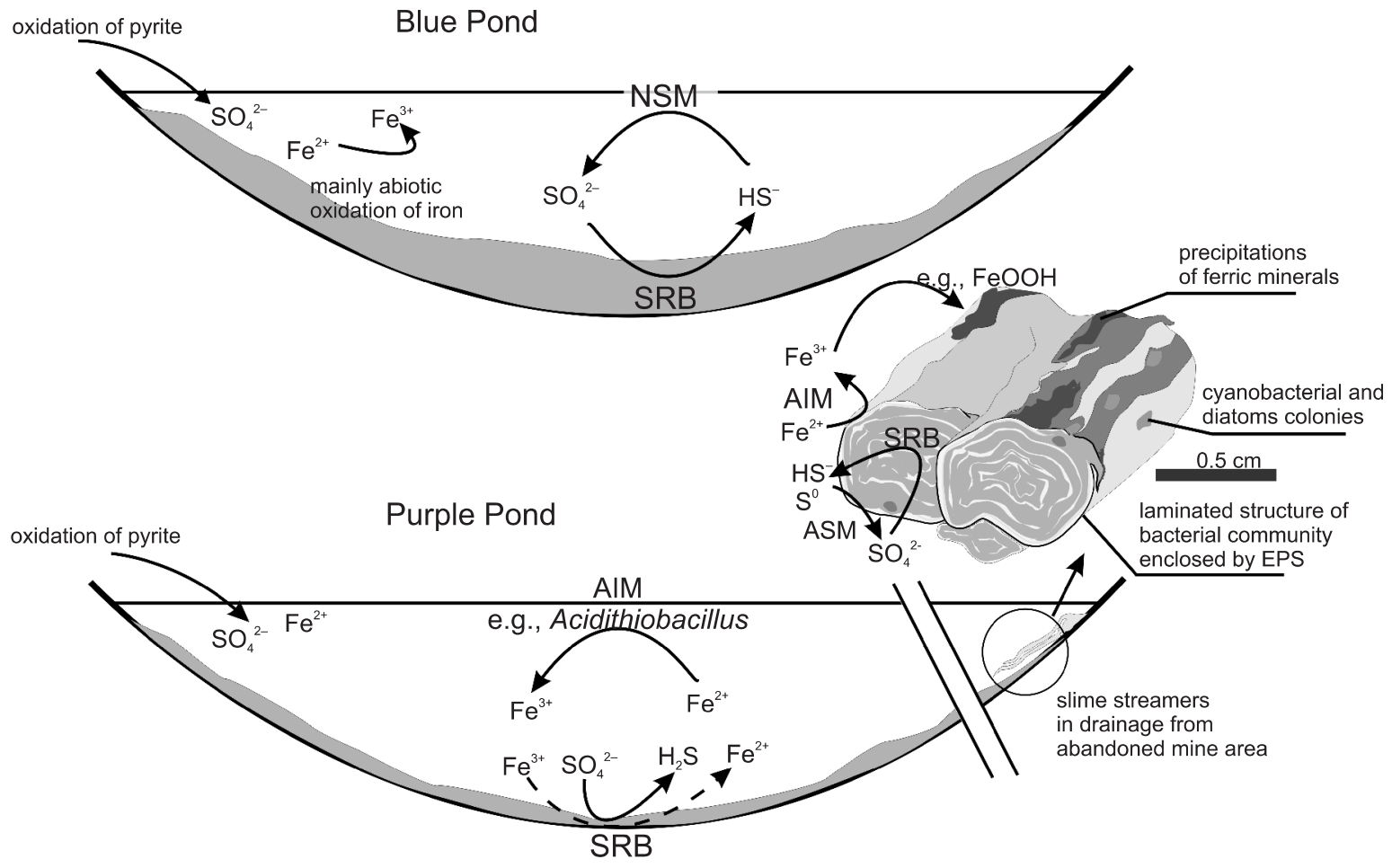

Fig. 9. The potentially most important processes in the water reservoirs studied having influence on the shape of the biogeochemical cycle of sulphur and iron

AIM - acidophilic iron-oxidizing microorganisms, ASM - acidophilic sulphur microorganisms, EPS - Extracellular polymeric substances, NSM - neutrophilic sulphur microorganisms, SRB - sulphate-reducing bacteria

to oxidize thiosulphate to sulphates, a process that is conducted by sulphur microorganisms preferring less acid settings.

The presence of organized microbial structures in the AMD outflow from the mine is a notable feature. The presence of these slime streamers was restricted to the uppermost stretch of the stream; likewise they did not occur in the acid Purple Pond, despite the fact that water samples from the stream and reservoir had an almost identical chemical composition. Therefore, it can be concluded that an important factor influencing the development of slime streamers is good water aeration, attainable in a small flowing stream, but an aspect limiting their growth is the availability of iron(II). With decrease of iron(II) concentration downstream, slime streamers disappeared completely. The structures described occur as layered biofilm and it is possible that they are a complex system of microorganisms duction of sulphates in the bottom deposits and oxidation of hydrogen sulphide by microorganisms preferring slightly acid and neutral conditions. In the Purple Pond, a process dominating among the obligatory or facultative chemolithotrophic microflora is most probably iron oxidation. This can be shawn by the abundance of weathering sulphate minerals containing $\mathrm{Fe}^{3+}$, such as copiapite, fibroferrite or slavikite, whereas ferrous sulphates occur only sporadically.

Acknowledgments. The studies were conducted in Geomicrobiology Laboratory at the Faculty of Geology, University of Warsaw and were supported by founds of Institute of Geochemistry, Mineralogy and Petrology (Faculty of Geology, University of Warsaw). The authors thank Reviewers for their remarks and comments which have improved this article. 


\section{REFERENCES}

Baker B.J., Banfield J.F. (2003) Microbial communities in acid mine drainage. FEMS Microbiology Ecology, 44: 139-152.

Balcerzak E., Dobrzyński D., Parafiniuk J. (1992) The effects of mineral alterations on the chemical composition of waters in the weathered zone of pyrite-bearing schists in Wieściszowice, Rudawy Janowickie Mts., W. Sudetes, Poland (in Polish with English summary). Annales Societatis Geologorum Poloniae, 62 (1): 75-93.

Baumgartner L.K., Reid R.P., Dupraz C., Decho A.W., Buckley D.H., Spear J.R., Przekop K.M., Visscher P.T. (2006) Sulfate reducing bacteria in microbial mats: changing paradigms, new discoveries. Sedimentary Geology, 185: 131-145.

Bond P.L., Druschel G.K., Banfield J.F. (2000) Comparison of acid mine drainage microbial communities in physically and geochemically distinct ecosystems. Applied and Environmental Microbiology, 66 (11): 4962-4971.

Ehrlich H. (2001) Geomicrobiology. New York: Mercel Dekker, Inc.: 153-177.

Fauque G., Legall J., Barton L.L. (1991) Sulfate-reducing and sulfur reducing bacteria. In: Variations in Autotrophic Life (eds. J.M.I., Shively and L.L. Barton). Academic Press Ltd.

Fortin D., Davis B., Beveridge T.J. (1996) Role of Thiobacillus and sulfate-reducing bacteria in iron biocycling in oxic and acidic mine tailings. Microbiology Ecology, 21: 11-24.

Gibson G. (1990) Physiology and ecology of the sulphate-reducing bacteria. Journal of Applied Bacteriology, 69: 769-797.

González-Toril E., Aguilera A., Souza-Egipsy V., López-Pamo E., Sánchez-España J., Amils A. (2011) Geomicrobiology of La Zarza-Perrunal acid mine effluent (Iberian Pyritic Belt, Spain). Applied and Environmental Microbiology, 77 (8): 2685-2694.

Hallberg K.B. (2010) New perspectives in acid mine drainage microbiology. Hydrometallurgy, 104: 448-453.

Harvey A.E., Smart J.A., Amis E.S. (1955) Simultaneous spectrophotometric determination of iron (II) and total iron with 1,10-phenanthroline. Analytical Chemistry, 27 (1): 26-29.

Hao O.J., Chen J.M., Huang L., Buglass R.L. (1996) Sulfate-reducing bacteria. Critical Reviews in Environmental Science and Technology, 26: 155-187.

Holt J.G., Krieg N.R., Sneath P.H., Staley J.T., Williams S.R. (2000) Bergey's Manual of Determinative Bacteriology, 9th ed. Lippincott Williams and Wilkins: 427-438.

Joeckel R.M., Ang Clement B.J., VanFleet Bates L.R. (2005) Sulfate-mineral crusts from pyrite weathering and acid rock drainage in the Dakota Formation and Graneros Shale, Jefferson County, Nebraska. Chemical Geology, 215: 433-452.

Johnson D.B. (1998) Biodiversity and ecology of acidophilic microorganisms. Microbiology Ecology, 27: 307-317.

Kappler U., Friedrich C.G., Truper H.G., Dahl C. (2001) Evidence for two pathways of thiosulfate oxidation in Starkeya novella (formerly Thiobacillus novellus). Archives of Microbiology, 175: 102-111.

Kolmert A., Wikstrom P., Hallberg K.B. (2000) A fast and simple turbidimetric method for the determination of sulfate in sulfate-reducing bacterial cultures. Journal of Microbiological Methods, 41: 179-184.
Koschorreck M. (2008) Microbial sulphate reduction at low $\mathrm{pH}$. FEMS Microbiology Ecology, 64: 329-342.

Leduc D., Leduc G., Ferroni G.D. (2002) Quantification of bacterial populations indigenous to acidic drainage streams. Water, Air and Soil Pollution, 135: 1-21.

Murad E., Schwertmann U., Bigham J.M., Carlson L. (1994) Mineralogical characteristics of poorly crystallized precipitates formed by oxidation of $\mathrm{Fe}^{2+}$ in acid sulfate waters. ACS Symposium Series: Environmental Geochemistry of Sulfide Oxidation, 14: $190-200$.

Nordstrom K., Alpers C.N., Coston J.A., Taylor H.E., McCleskey R.B., Ball J.W., Ogle S., Cotsifas J.S., Davis J.A. (1999) Geochemistry, toxicity, and sorption properties of contaminated sediments and pore waters from two reservoirs receiving acid mine drainage. Proceedings of the Technical Meeting Charleston South Carolina March 8-12, 1999; Volume 1 of 3 Contamination From Hard-Rock Mining, Water-Resources Investigation Report 99-4018A.

Parafiniuk J. (1996) Sulfate minerals and their origin in the weathering zone of the pyrite-bearing schists at Wieściszowice (Rudawy Janowickie Mts, Western Sudets). Acta Geologica Polonica, 46 (3-4): 353-414.

Parafiniuk J., Siuda R. (2006) Schwertmannite precipitated from acid mine drainage in the Western Sudetes (SW Poland) and its arsenate sorption capacity. Geological Quarterly, 50 (4): 475-486.

Postgate J.R. (1984) The Sulphate Reducing Bacteria. Cambridge University Press.

Praharaj T., Fortin D. (2004) Indicators of microbial sulfate reduction in acidic sulfide-rich mine tailings. Geomicrobiology Journal, 21: 457-467.

Pronk J.T., Meulenberg R., Hazeu W., Bos P., Kuenen J.G. (1990) Oxidation of reduced inorganic sulphur compounds by acidophilic thiobacilli. FEMS Microbiology Reviews, 75: 293- 306.

Rampinelli L.R., Azevedo R.D., Teixeira M.C., Guerra-Sá R., Leão V.A. (2008) A sulfate-reducing bacterium with unusual growing capacity in moderately acidic conditions. Biodegradation, 19: 613-619.

Sánchez-España J., López-Pamo E., Pastor E.S., Ercilla M.D. (2008) The acidic mine pit lakes of the Iberian Pyrite Belt: an approach to their physical limnology and hydrogeochemistry. Applied Geochemistry, 23: 1260-1287.

Sánchez-Andrea I., Rodríguez N., Amils R., Sanz J.L. (2011) Microbial diversity in anaerobic sediments at Rio Tinto, a naturally acidic environment with a high heavy metal content. Applied and Environmental Microbiology, 77 (17): 6085-6093.

Silverman M.P., Lundgren D.G. (1959) Studies on the chemoautotrophic iron bacterium Ferrobacillus ferrooxidans I. An improved medium and harvesting procedure for securing high cell yields. Journal of Bacteriology, 77: 642-647.

Webster J.G., Nordstrom K., Smith K.S. (1994) Transport and natural attenuation of $\mathrm{Cu}, \mathrm{Zn}, \mathrm{As}$ and $\mathrm{Fe}$ in the acid mine drainage of Leviathan and Bryant Creeks. ACS Symposium Series: Environmental Geochemistry of Sulfide Oxidation, 17: 244-260. 